\title{
Genetics and Society-Educating Scientifically Literate Citizens: Introduction to the Thematic Issue
}

\author{
Kostas Kampourakis • Thomas A. C. Reydon • George P. Patrinos • \\ Bruno J. Strasser
}

Published online: 29 October 2013

(C) Springer Science+Business Media Dordrecht 2013

\section{The Need for Genetics Literacy}

Advances in molecular genetics and genomics, and their applications in personalised medicine and other fields, are raising important socio-scientific issues. If the aim of science teaching is to educate scientifically literate citizens, the implications of current genetic and genomic technologies for our lives have to be addressed in science courses. Educational policies in all industrialized societies consider science literacy as a main goal of education. The science standards in several European Union member states (Eurydice Network 2011) and the United States (National Research Council 2012) have stated similar goals. Given the key role attributed to genes as determinants of human identity, health, and behavior, genetics is a scientific field about which science literacy is particularly important. With the wide media attention given to the identification of the genetic basis of human traits and the increasing availability of direct-to-consumer genetic tests it is important that non-experts understand what kinds of reliable genetic knowledge can be acquired and what their implications for society are. Thus, science educators and teachers need to be informed about the current status of genetics and genomics research, the technological state of the art, its biomedical applications, and the relevant ethical issues. The contribution of research scientists to the public understanding of science is important in this respect (Reydon et al. 2012).

K. Kampourakis $(\bowtie) \cdot$ B. J. Strasser

Biology Section and IUFE, University of Geneva, Geneva, Switzerland

e-mail: Kostas.Kampourakis@unige.ch

B. J. Strasser

e-mail: Bruno.Strasser@unige.ch

T. A. C. Reydon

Institute of Philosophy, Center for Philosophy and Ethics of Science (ZEWW) and Centre for Ethics and Law in the Life Sciences (CELLS), Leibniz Universität Hannover, Hannover, Germany

e-mail: reydon@ww.uni-hannover.de

G. P. Patrinos

Department of Pharmacy, School of Health Sciences, University of Patras, Patras, Greece

e-mail: gpatrinos@upatras.gr 
Based on Roberts (2007, pp.729-730), one can identify two core competencies relevant to instruction aiming at science literacy: (1) understanding science concepts and aspects of the nature of science (including inquiry and explanatory skills), and (2) engaging in argumentation and decision making practices about socio-scientific issues. These competencies represent distinct, but closely interdependent, aims of science education. On one hand, understanding and using science concepts and explanations is a prerequisite for being able to argue about socio-scientific issues. For example, knowledge about what stem cells are and how they can be obtained may affect the moral judgments that people make about their use in research and therapy.

On the other hand, engaging in argumentation and decision-making practices for socioscientific issues provides opportunities to raise new scientific questions and motivate students to understand the scientific issues with greater depth. For example, students might argue against a ban on human embryonic stem cell research because of the potential benefits; or they might argue in support of such a ban because they learned about the potential of using induced pluripotent stem cells. Because of the centrality of science content in arguments like these, such engagement in discussions of socio-scientific issues can promote knowledge and understanding of science content. Like science literacy in general, then, genetics literacy has two distinct components. One is related to the content traditionally taught in classrooms (knowledge about DNA, genes, chromosomes, patterns of inheritance, etc.) and the other to questions that students may encounter as citizens (the ethical questions related to genetic testing, genetic engineering and genetically modified organisms for example).

Unfortunately, public understanding of genetics is characterized by serious shortcomings (see Condit 2010, for a review of relevant research). Students' conceptions mainly reflect naive genetic determinism, i.e. the view that genes alone can determine the presence or absence of complex traits. Recent research, however, shows that complex traits result from the interaction of many genetic, environmental, and behavioral factors with molecular networks. The contemporary presentation of genetics in schools that teaches students that genes "control" or "code for" individual characteristics is a misrepresentation of what is currently known about the effects of the genetic material. Genome-wide association studies (GWAS), i.e. studies aiming to identify all genetic factors related to health and disease, have shown that the influence of single genetic factors on disease is small. Even for traits with strong familial clustering, the most probable candidate genetic variants explain only a small percentage of the overall inherited risk for a disease (Altshuler et al. 2008; Dermitzakis and Clark 2009). Simply finding associations between DNA sequences and disease risk does not provide clinically useful information. Therefore, scientists' attention has now turned towards understanding processes and mechanisms involved in the genetic basis of diseases, e.g. how genetic and environmental perturbations affect molecular networks which in turn affect disease (Schadt 2009), the effect of genetic variants and environmental influences at the level of cells (cellular phenotyping) (Dermitzakis 2012) or what epigenetic variation contributes to complex phenotypes (Kilpinen and Dermitzakis 2012). A great proportion of students' understanding of genetics is thus based on a misrepresentation of the actual state of genetics research. Why this is the case?

It seems that the content of genetics taught in schools does not accurately represent the knowledge in the field, and especially the knowledge that is relevant to understand current socio-scientific issues. Research findings cause concern about the prevalence of outdated models that enhance mistaken notions of naive genetic determinism, or the view that there are "genes for" traits (Nelkin and Lindee 2004). On one hand, as a recent study has revealed, the presentation of genetics in biology textbooks does not take into account the 
complexities of development, and promotes an overly deterministic view of genetics (see Gericke et al., this issue). On the other hand, as a recent study of teachers' conceptions of genetic determinism in several countries has shown, even biology teachers often hold simplistic (or inaccurate) views such as genetic determinism (see Castera and Clement, this issue). If outdated models of genetics remain in textbooks and if teachers are not sufficiently familiar with contemporary knowledge of genetics and development, it should be no surprise that both high school students (e.g. Mills Shaw et al., 2008) and undergraduates (Smith and Knight 2012) hold deep misconceptions about genetics.

Simple, monogenic, models of cause-effect relationships (e.g. gene-phenotype) are more easily adopted by students than realistic models in which multiple factors (genes, gene regulation, cell environment, body environment and external environment) affect the phenotype (see Jimenez, this issue). Since naive genetic determinism is an important misconception among students that negatively affects their understanding of genetics and their engagement in argumentation and decision-making practices, genetics instruction should develop new kinds of school knowledge that reflect more accurately what genes can and cannot do by emphasizing the complexities of inheritance (Dougherty 2009). There are many options: "genes for" concepts might be replaced by more inclusive ones (concepts of DNA, or genetic material, for example) (Burian and Kampourakis 2013); or classic Mendelian genetics could be taught not as the norm but as a specific case (Jamieson and Radick 2013). Textbooks might also be rewritten to be freed from any overly simplistic deterministic language. But achieving a kind of genetics literacy that will allow citizens of the 21 st century to engage in the growing number of genetics socio-scientific issues will require coordinated efforts by educators and scientists. This thematic issue is intended as a first step in that direction.

\section{Overview of the Contents of the Thematic Issue}

This thematic issue contains contributions from historians and philosophers of science, as well as science educators. History is especially important in this case as understanding what happened in the past may be quite enlightening in addressing important issues in the present. Thus, the first article by Diane Paul, titled "What Was Wrong with Eugenics? Conflicting Narratives and Disputed Interpretations", explains that understanding what eugenics was about is useful for addressing contemporary issues relevant to reproductive genetics (or "reprogenetics"). The author thus explains that several very different, and sometimes diametrically-opposed, morals have been drawn from the history of eugenics. What is more important is that the history of eugenics cannot simply provide direct guidance and insights for contemporary debates. A careful study of history shows that things were more complicated than commonly thought. For example, there were plenty of racists and reactionaries in the eugenics movements, but even in Germany eugenics also found support amongst anti-racists and progressives, even prominent Jews, before the Nazi seizure of power. Or that the "feebleminded" should not be allowed to breed was taken for granted even by self-declared critics of eugenics. Paul consequently suggests that one should be careful when using history to develop arguments for contemporary debates. The lessons of history are not self-evident, historical evidence needs to be carefully interpreted, and when this is done lessons and counter-lessons can be derived.

In the next article, titled "The Allusion of the Gene: Misunderstandings of the Concepts of Heredity and Gene", Raphael Falk describes how the concepts "heredity" and particularly "gene" were used during the twentieth century. The important point to take into 
account is that different "gene" concepts were used by scientists based on their explanatory aims. The gene of classical genetics was different from the gene of molecular genetics. While it seemed that the advance of molecular genetics would eventually make possible to structurally individuate genes, it was eventually shown that the concept of "gene" is meaningless outside its cellular context. The author notes that however the notion of "genes for" traits or "genes for" diseases became quite widespread in the public discourse on genetics and he explains that this is a simplistic, reductionist perception of genes which should be avoided. The author concludes that explaining the role of science to non-experts is also important: science is rather asking questions rather than provides definite answers.

That understanding the nature of science is important for educating citizens literate in genetics is argued in detail in the next article by Norman Lederman, Allison Antink and Stephen Bartos titled "Nature of Science, Scientific Inquiry, and Socio-scientific Issues Arising from Genetics: A Pathway to Developing a Scientifically Literate Citizenry". The authors illustrate how teachers can use contemporary Socio-scientific issues to teach students about the nature of science but also address the science content which is relevant to these issues. Taking genetically modified foods, genetic testing and stem cell research as examples, the authors suggest that a reflective, explicit approach to teaching about the nature of science and the process of scientific inquiry can be used along with the relevant socio-scientific issue to improve students' understandings of these as well as of the relevant science subject matter. Having acquired sufficient knowledge of subject matter, nature of science and scientific inquiry students will then be able to make more informed decisions about important socio-scientific issues.

Understanding the nature of science and the process of scientific inquiry is of course important, but the articles in this thematic issue mostly focus on knowledge about genetics: from where it is acquired and how it develops. In their article titled "Young Children's Reasoning About Physical and Behavioural Family Resemblance: Is There a Place for a Precursor Model of Inheritance?" Marida Ergazaki, Aspa Alexaki, Chrysa Papadopoulou and Marieleni Kalpakiori describe their research aiming at developing an early years' learning environment about inheritance. To achieve such a learning environment they investigated what kinds of explanation pre-school children provided for whether and why offspring share physical and behavioral traits with parents and which mechanism could better explain the shared physical traits. The authors found that children could not clearly distinguish between the origin of the physical and behavioral traits. However, based on their findings they also conclude that the development and implementation of an early years' learning environment in the context of inheritance may be possible. Details notwithstanding, understanding how children think about inheritance and addressing their intuitive explanations about the relevant phenomena might provide a solid basis for any future genetics instruction.

Another important question is what influence the public discourse on genetics has on children's understanding. Jenny Donovan and Grady Venville, in their article "Blood and Bones: The Influence of the Mass Media on Primary Students' Understandings of Genes and DNA", report findings from their study with elementary school students' understanding of genetics. Previous research had shown that children considered genes and DNA in a different way and it was supposed that this misunderstanding was due the mass media. Thus, they examined the media habits and conceptions about genes and DNA of Australian children. Results indicated that children perceived television to be their main source of information about genetics, which was mostly about uses of DNA outside the body such as crime solving or resolving family relationships than about its biological nature and 
function. Donovan and Venville conclude that mass media have an influence on children's understanding of genetics, and they suggest that instruction about this topic could be introduced in elementary schools in order for children to understand scientific concepts before their misconceptions develop.

In the next article, titled "Young People's Understandings of Gene Technology: From Flavr Savr Tomatoes to Stem Cell Therapy", Jenny Lewis presents findings from a research on 14-16 year old students' knowledge and understanding of basic genetics and gene technologies, comparing the responses of 482 students in 1995 with those of 154 students in 2011. Students in 2011 overall showed a better understanding of the subject matter taught, but they had difficulties in developing coherent explanations while holding misunderstandings and confusions on some topics. Students in 2011 also had greater awareness of ethical issues and of the factors that should be taken into account before coming to a decision about socio-scientific issues. Lewis suggests that a genomics curriculum for scientific literacy should be developed. In doing so, it would not be enough to only think about what kind of content is taught but also how it is taught and how it could be assessed, with emphasis put on supporting the development of coherent conceptual frameworks which would enable students to appropriately use their content knowledge.

There are many important factors that influence teaching but classroom practice suggests that textbooks and teachers are the two most important ones. This is the focus of the next two articles. In the first, titled "Conceptual Variation or Incoherence? Textbook Discourse on Genes in Six Countries", Niklas Gericke, Mariana Hagberg, Vanessa Santos, Leyla Oaquim and Charbel El-Hani present and compare previous results of independent studies on the presentation of genes and gene function in high school textbooks from six different countries. The authors' results indicate that a common textbook discourse on genes and their function exists in the textbooks from the different countries. A very important finding is that the most frequently models used in the textbooks analyzed are old ones which promote an often deterministic and mechanistic view of Genetics. Consequently, teachers and students who use these textbooks do not have the opportunity to learn about the recent developments in our understanding about genes which has been increasingly challenging genetic determinism. The authors suggest that making students aware of these developments is important, as it is to make explicit that different gene concepts are used in different research fields of the life sciences. If this is not achieved, confusions about genes may persist and have implications for how genes are understood, usually enhancing notion of strong genetic determinism.

Interestingly enough, such views are even held by biology teachers, as suggested by Jeremy Castera and Pierre Clément in their article "Teachers' Conceptions About Genetic Determinism of Human Behaviour: A Survey in 23 Countries". In their study of 8,285 inservice and pre-service teachers from 23 countries that aimed to investigate teachers' conceptions related to the genetic determinism of human behavior, they found that several of them hold such conceptions. Teachers relied on genetic determinism to justify intellectual likeness between individuals such as twins or to justify gender differences or the superiority of some human ethnic groups. Differences were significant between countries, with such views held by more teachers in, for example, African countries rather than European countries. Another important finding was that the level of teachers' training influences their conceptions, mainly related to genetic determinism about groups, with innatism decreasing when the level of teacher training increases. This means that supporting teacher training in this domain could have important implications for teaching for scientific literacy. 
In the next article, titled "Genetics Curriculum and Assessment: The Status of Instruction for Bioscience Majors in the United States", Teresa McElhinny, Michael Dougherty, Bethany Bowling and Julie Libarkin provide a review of the state of genetics instruction in the United States, with particular attention to the goals and assessments that inform curricular practice. Their analysis of syllabi and textbooks indicates that genetics instruction focuses on the fundamentals of DNA and Mendelian genetics. However, and interestingly enough, faculty members seem to consider other topics such as the applications of genetics to society or the environment, as equally or even more important than the fundamental concepts usually taught. This seems to suggest that teaching aims are not properly set before curricula are designed. The authors also suggests that before any curricular revision takes place, broadly applicable, valid, and reliable assessments instruments should be developed in order to measure the efficacy of instruction. Revision of curricula could then based on the results and conclusions of such measurements.

In the next article, "Determinism and Underdetermination in Genetics: Implications for Students' Engagement in Argumentation and Epistemic Practices”, Maria Pilar JiménezAleixandre focuses on students' engagement in epistemic practices or practical epistemologies in the context of genetics. The author suggests that in order to support these practices during genetics instruction, issues about determinism and underdetermination should be taken into account. She suggests that particular difficulties may be due to the how causality in genetics is perceived as for example there are no single cause and effect relationships but often there is correspondence between a set of factors and a range of potential effects. Thus, in order to support students to be able to understand and evaluate information related to genetics, reductionism and determinism in genetics are issues that must be addressed. One way to do this, the author suggests, is to support students in developing more sophisticated epistemic practices or practical epistemologies in the context of genetics.

Socio-scientific issues relevant to genetics are also the topic of the article titled "Reframing and Articulating Socio-scientific Classroom Discourses on Genetic Testing from an STS Perspective" by Dirk Jan Boerwinkel, Tsjalling Swierstra and Arend Jan Waarlo. The authors argue that technology and society are no longer seen as independent entities but rather as shaping each other, but this notwithstanding public debates on technological innovations still overemphasize the risks. The authors also suggest that, in the case of genetic testing, raising awareness of the influences of society on the development, use and availability of genetic tests is a first step in enhancing student agency; that bringing up for discussion the influence of technology on morality may help challenge the idea that technology is constrained by ethics; and that addressing the uncertainty in conclusions from genetic testing in classroom may be helpful in developing a realistic view of science and technology and life. These can be achieved through dialogue and participative decision-making in classroom, which nevertheless raises the demands in terms of teachers' qualifications. The authors finally state that they are in the process of empirically testing these suggestions in classrooms.

In the closing article of this special issue, "The Perfect Storm: Genetic Engineering, Science, and Ethics", Bernard Rollin draws an analogy between discussions on ethical and social issues regarding genetics and what has come to be called a "perfect storm"- a storm in which a number of causal factors happen to work together in such a way that they mutually enforce one another and together create a much more forceful storm than would have occurred under normal circumstances. Rollin identifies six such factors that conspire to create a societal "perfect storm" in discussions on genetics and genomics: a social demand for ethical discussion, scientific illiteracy, poor social understanding of ethics, a 
"Gresham's Law for Ethics", scientific ideology, and vested interests that dominate ethical discussion. Especially what Rollins calls "Gresham's Law for Ethics" is interesting (see also Rollin, 2006; Reydon et al. 2012). The name of this "law" refers to Thomas Gresham, a merchant and royal financial advisor in 16th century England. Gresham argued that in cases in which two types of currency are in circulation, one of which is perceived as solid and the other is seen as less stable, the latter currency will tend to push the solid currency out of circulation. After all, driven by fears of devaluation people will tend to hoard the tokens of the solid currency that they receive and prefer to spend whatever tokens of the less stable currency they have before taking recourse to spending solid currency. Something similar, Rollin argues, can happen in public discussions on science and technology, because new technologies bring us into unexplored ethical territory such that bad arguments may easily displace good arguments. In conjunction with the other factors that Rollin points to, such as deficient levels of scientific literacy and deficient levels of understanding of ethical reasoning and ethical positions, "Gresham's Law" can create a disastrous situation for public discussions on societal issues that arise with respect to new technologies, including genetics and genomics. Rollin, however, does not only highlight this problem, but also discusses what could be done to mitigate it.

\section{Outlook}

Overall, all the articles outlined above nicely summarize and provide a first introduction to the various issues that should be addressed in public debates related to genetics, genomics and their uses in achieving the goals of personalized medicine. Education of healthcare professionals and raising awareness among the general public about genetics and genomic medicine are both key issues that, if properly addressed, will catalyze and expedite the implementation of genomic medicine into mainstream medical practice. But much remains to be done and we believe that in order to develop fruitful approaches, collaborative and interdisciplinary work between professionals from various relevant fields is required. This thematic issue is the produce of such a collaboration.

Elsewhere (Reydon et al. 2012), three of us have already pointed to the various contributions that practicing scientists, science educators and communicators, and historians and philosophers of science can provide to achieving higher levels of scientific literacy about genetics and genomics. We will not repeat these points here, but rather close by highlighting what we believe is the most important issue, namely the need for close, interdisciplinary collaborations between research scientists, developers of new genetic and genomic technologies and applications, science educators and communicators, historians and philosophers of science, and bioethicists. No discipline or field of work will by itself be able to adequately resolve the problem of scientific literacy, we believe. It is only when the specific knowledge from all these (and perhaps from still other) fields of work are brought together that in conjunction they might be able to create a more powerful solution to the problem than each of these fields will be able to provide by itself. What we envisage is something similar to the "perfect storm" that Rollin pointed to-albeit that we envisage a "perfect storm" in a positive sense.

Acknowledgments The idea for this issue emerged from the "Genetics and Society" conference that was held in Athens, Greece, in November 2011. The conference was co-organized by the Golden Helix Institute of Biomedical Research (http://www.goldenhelix.org) and GEITONAS School (http://geitonas.edu.gr). We thank Michael Matthews for providing us with the opportunity to work on a thematic journal issue on this topic. The authors declare no conflicts of interest. 


\section{References}

Altshuler, D., Daly, M. J., \& Lander, E. S. (2008). Genetic mapping in human disease. Science, 322, $881-888$.

Burian, R. M., \& Kampourakis, K. (2013). Against "genes for": Could an inclusive concept of genetic material effectively replace gene concepts? In K. Kampourakis (Ed.), The philosophy of biology: A companion for educators (pp. 597-628). Dordrecht: Springer.

Condit, C. M. (2010). Public understandings of genetics and health. Clinical Genetics, 77, 1-9.

Dermitzakis, E. T. (2012). Cellular genomics for complex traits. Nature Reviews Genetics, 13, 215-220.

Dermitzakis, E. T., \& Clark, A. G. (2009). Life after GWA studies. Science, 326, 239-240.

Dougherty, M. J. (2009). Closing the gap: Inverting the Genetics curriculum to ensure an informed public. The American Journal of Human Genetics, 85, 6-12.

Eurydice Network. (2011). Science education in Europe: National policies. Brussels: Practices and Research Education, Audiovisual and Culture Executive Agency.

Jamieson, A., \& Radick, G. (2013). Putting Mendel in his place: How curriculum reform in Genetics and counterfactual history of science can work together. In K. Kampourakis (Ed.), The philosophy of biology: A companion for educators (pp. 577-595). Dordrecht: Springer.

Kilpinen, H., \& Dermitzakis, E. T. (2012). Genetic and epigenetic contribution to complex traits. Human Molecular Genetics, 21(R1), R24-R28.

Mills Shaw, K. R., Van Horne, K., Zhang, H., \& Boughman, J. (2008). Essay contest reveals misconceptions of high school students in genetics content. Genetics, 178, 1157-1168.

National Research Council Committee on Conceptual Framework for the New K-12 Science Education Standards. (2012). A Framework for K-12 science education: Practices, crosscutting concepts, and core ideas. Washington: National Academies Press.

Nelkin, D., \& Lindee, S. M. (2004). The DNA mystique: the gene as a cultural icon. Ann Arbor: University of Michigan Press.

Reydon, T. A. C., Kampourakis, K., \& Patrinos, G. P. (2012). Genetics, genomics and society: the responsibilities of scientists for science communication and education. Personalized Medicine, 9, 633-643.

Roberts, D. A. (2007). Scientific literacy/science literacy. In S. K. Abell \& N. G. Lederman (Eds.), Handbook of research on science education (pp. 729-780). Mahwah, NJ: Erlbaum.

Rollin, B. E. (2006). Science and ethics. Cambridge: Cambridge University Press.

Schadt, E. E. (2009). Molecular networks as sensors and drivers of common humans diseases. Nature, 461, $218-223$.

Smith, M. K., \& Knight, J. K. (2012). Using the genetics concept assessment to document persistent conceptual difficulties in undergraduate genetics courses. Genetics, 191, 21-32. 